Munise Duran

Inonu University

Turkey
Original scientific paper

UDC: 371.136

DOI: $10.5937 /$ IstrPed2002184D

\title{
THE EVALUATION OF THE EDUCATION PROGRAM FOR "THE CHILDREN AGED 0-36 MONTHS" BY TEACHERS
}

\begin{abstract}
The aim of this study is to reveal the teachers' evaluation of the educational program for infants and children aged 0-36 months old. In order to collect data, 18 teachers from day care centers and nurseries in Malatya province were interviewed. The Educational Program prepared for infants and children aged 0-36 months old by the General Directorate of Basic Education of the T.R Ministry of National Education was evaluated using the interview form developed by the researcher. The findings of the research were analysed by means of descriptive method. The following results were obtained: teachers only performed the activity of "sending a notification to families" out of all the available participation activities. Among the adoption and developmental indicators, they had difficulties in designing activities in order to gain cognitive and psychomotor development indicators, and in evaluating emotional development. They used the plans already available in the market for activity planning, and they mostly preferred finger games. According to the results obtained in the evaluation, the teachers did not evaluate themselves at all, and they evaluated the program and the children at a limited level.
\end{abstract}

Keywords: Early childhood education, early childhood teacher, preschool education, program evaluation, nursery program.

Beginning at birth and continuing throughout the primary school years of the child, early childhood education is a systematic process supporting all the developmental areas, teaching the child cultural, spiritual, national, moral and human values of the society, supporting their creativity by increasing the power of emotion and thought in children, and helping to raise self-confident, self-expressive and independent individuals (Yilmaz, 2003). Early childhood education also prepares children for learning (Kleyn and Shaughnessy, 2012). Early childhood education is carried out in accordance with "pre-school educational programs" and "educational programs for infants and children aged 0-36 months old" in educational institutions. These institutions consist of playschools, kindergartens and practice classes under the body of the Ministry of Education, and nurseries, nursery and daycare centers, kindergartens, childcare centers and childcare dormitories within the Ministry of Family and Social Policies (Derman and Basal, 2010). The pre-school educational program is designed for children aged 36 to 72 months old. The educational program for infants and children aged o36 months old is designed for children going to nurseries and childcare centers.

The first program-related studies on early childhood education date back to the 1980 s. Following the decision made in the $10^{\text {th }}$ National Education Council in 1981, it was Decided to develop pre-school educational programs and to prepare handbooks for kindergarten teachers (Talim Terbiye Kurulu Baskanligi, 1981). In these years, teachers adopted subject- 
oriented teaching, therefore, made plans in line with the objectives and target behaviours they had written according to the units published in the Journal of Notices at the beginning of the school year. This led to the lack of unity in education, and moreover, other developmental areas were not supported adequately as teachers focused on cognitive learning in children (Gelisli and Yazici, 2012).

The Council of Higher Education decided to implement the pre-school educational program in accordance with its linked note as of the academic year of 1988-1989, on condition that the pre-school educational program would be tested and developed upon the proposal of the Ministry of National Education in 1989. This program was prepared for playschools, kindergartens, nurseries and practice classes for children aged 4-5 (Tebligler Dergisi, 1989). The $0-4$ age group was not included in the first program. According to the decision made in 1994, the education of the 0-4 age group was first come up with the decision to implement the nursery, kindergarten and playschool program instead of the pre-school education program adopted in 1989 (Tebligler Dergisi,1994). The nursery program is for infants and children aged 0-36 months old, the playschool program is for children between 36 and 72 months old, and the kindergarten program is for children between 60 and 72 months old. In the nursery program, there are objectives and target behaviours in 5 developmental areas: cognitive, language, physical, social-emotional and self-care areas. Furthermore, the developmental characteristics of the children were given according to three different developmental periods: 0-12 months, 13-24 months, 25-36 months (Tebligler Dergisi, 1994). After this implementation, pursuant to the decision made in 2002, it was decided to close the pre-school educational programs, kindergarten and playschool programs and to continue the implementation of the nursery program. Therefore, instead of kindergarten and playschool programs, there were two programs established, a pre-school education program for children aged 36-72 months old and a nursery program for infants and children aged 0-36 months old. The program was revised in 2006, and a new pre-school educational program was prepared and put into practice for children aged 36-72 months old (Tebligler Dergisi, 2006).

The nursery program was renewed in 2013, that is, 19 years later. After the implementation of the new program was accepted, the program prepared in 1994 was closed (Tebligler Dergisi, 2013). According to this program, it was stated that the program as developed in order to support the development of motor, social-emotional, language and cognitive areas through the rich learning experiences of children and to support their health, care, and nutrition in the most appropriate way. (Milli Egitim Bakanligi, 2013). Since the focus is set upon supporting children's cognitive, language, social-emotional, and motor development areas, indicators to consider for planning education with respect to these areas are given in the existing program. These indicators are included in the program as follows: There are 65 indicators in the area of cognitive development, 54 indicators in the area of language development, 46 indicators in the social-emotional area, and 146 indicators in the area of motor development (gross motor 81, fine motor 65). Considering children's level of development should be the teachers' main priority when selecting these indicators.

While the educational program is designed for infants and children aged 36-72 months old, the daily educational schedule is prepared. The daily educational schedule is a plan that shows the activities and routine activities planned for the day. This plan is made in two separate categories for children aged 0-24 months and 24-36 months. The daily educational flow for children aged 0-24 months was designed as arrival to the institution, free time, activity time, garden/outdoor time, lunch, activity time, garden/outdoor time, leaving the institution and 
free time. Routine activities are performed by observing them before each activity such as changing diapers, sleeping, and eating. The daily educational flow for children aged 24-36 months is as follows: arrival to the institution, group time (starting the day), activity time, lunch, activity time, group time (evaluation of the day), leaving the institution. In the daily educational flow, the educator will specify only what they will do and will not go into detail. In the activity plan, the planned activity is explained in detail in order to provide the specified developmental indicators. For this reason, the educational plan includes the name of the activity, developmental indicators, materials, learning process, security measures, adaptation and evaluation sections. The learning process in the plan is the part where the materials, methods and techniques required for performing the activity are clearly explained so that the specified development and indicators can be achieved. The adaptation part is where the activity is adapted to the disability of the child/baby who has special needs if he has any. In the evaluation part of the activity, the activity is evaluated together with children by using openended questions during and at the end of the activity. In the program for those with 0-36 months of age, the general evaluations are carried out in three different dimensions, namely the recognition and evaluation of the child, the evaluation of the program and the selfevaluation of the educator. To get to know the children and evaluate them, development observation forms were prepared. These forms show the cognitive, language, socialemotional and motor development levels of babies/children on a monthly basis. Development observation forms should be used every month for babies/children between 0-12 months of age, once every three months for those between 12-24 months of age and with a six-month interval for those with 24-36 months of age in order to evaluate their developmental characteristics. In addition, portfolios are used in the identification and evaluation of children (Milli Egitim Bakanligi, 2013). Portfolios are children's developmental files that include a variety of products and results in different areas of development to make an overall evaluation of the children. In the portfolios, files related to family information, observations made about the child by the teacher at different times, anecdotes about the child and family, personal information of the child, photographs, video recordings, artworks chosen by the child, projects, development checklists and the results of some tests (Morpa, 2010). The evaluation of the program consists of the evaluation of the activity plan and the whole group time (time of evaluating the day) in the daily educational flow. This includes the sum of the sections in which the activity is evaluated during and at the end of the process, asking questions about remembering and evaluating each activity performed with children within the group time before leaving the institution. In the self-evaluation of the educator, it is aimed that the teacher evaluates his work in or outside the educational environment with a critical point of view. Within this scope, the educator's self-evaluation form was created. In this form, educators are expected to evaluate themselves in nine categories: family, nutrition, ethics, program, areas of development, security and health, communication, material, personal and professional development. If needed, the educator can write down his / her opinion in the description of the items in these categories when determining the level of self-compliance.

The educational program for infants and children aged o to 36 months old is designed for children going to nurseries and day care centers. Nurseries and Day Care Centres have been defined as places established to provide the child with motherly care, to improve the wellbeing of the child and the family, and to solve family problems caused by the changing life conditions, economic and social environment (Resmi Gazete, 1966). The first law to be issued by the Ministry of Health and Social Welfare in 1953 for nurseries is the regulations about the conditions to employ pregnant or lactating women and breastfeeding rooms and nurseries. In these regulations, if more than 300 women were recruited in a workplace, it would be 
obligatory to open a nursery for their children between the ages of 1-6 in order for the mothers to leave their children there and for their children to be taken care of. (Resmi Gazete, 1953). In the Official Gazette dated 8 September 2016, Age ranges for Nursery and Day Care Centres are specified as follows: "The Nursery is established within the framework of the Decree-Law No: 633 and the relevant legislation and provides services to children aged 0-24 months; the Day Care Centre is established within the framework of the Decree-Law No: 633 and the relevant legislation and provides services to children aged 25-66 months," (Resmi Gazete, 2016).

\section{Purpose}

In this study, the importance of the nursery program prepared by the General Directorate of Basic Education of the Ministry of National Education was highlighted through the teachers' evaluation of the educational program for infants and children aged 36-72 months old. For this purpose, answers were sought for the following questions:

1. What are the views of the teachers in terms of the suitability of the development and its indicators in the program for the children (age, level of development, etc.)?

2. How do teachers make their evaluations?

a) What are the points they pay attention to when preparing the activities?

b) What are the resources they use when planning activities?

c) What are the most designed activities?

d) To what extent do they include family participation activities in their activities?

e) What are their suggestions for the program?

\section{Method}

The research is an internal case study, one of the qualitative research methods, for evaluation. Qualitative research utilizes qualitative data collection methods such as observation, interviews, and document analysis. It is a type of research in which a qualitative process is followed for presenting the perceptions and events in a natural environment in an integrated and realistic way (Yildirim \& Simsek, 2011). Internal case studies are carried out in special cases such as a program of interest, a curriculum or a conference (Stake, 1995). Qualitative case studies are an in-depth description of a system or a structure (Merriam, 2009). In order to describe this system, the researcher analyses the data obtained from several sources (e.g. interviews, observations, documents) (Creswell, 2007). Evaluation studies are carried out to determine the effectiveness of a program, the effectiveness of the product or the continuation of what is being evaluated, and its generalizability (Patton, 2002).

\section{Data Collection Tools}

In order to collect the data, the interview form that was created by the researcher was used. In the case of studies, data are usually gathered from interviews, observations and documents (Merriam, 2009). The interview questions prepared by the researcher were presented to the academicians specialized in the field. As a result of the opinions obtained, a pilot implementation was executed; some questions were edited, and the final version was formed. In this respect, it can be said that the validity and reliability of the data collection tool were increased. The questions were prepared as open-ended questions and asked in an interview fashion. The interview form consists of two parts. The first part includes the 
teachers' demographic information. The second part consists of questions about the program. In the study, all the teachers who educated children aged between 0-36 months in 11 Day Care Centres and Nurseries in Malatya province were reached, and the data were recorded using an audio recording device. The researcher applied to the Provincial Directorate of Family, Labour and Social Services of Malatya Governorship in written form for the necessary permits and got permission. She reached the teachers of the 0-36 months' age group at all private nursery and day-care centers in the province, told them about the research subject, and conducted the interviews with the teachers who wanted to participate in the research on the principle of volunteerism. Interviews were conducted either alone in an empty classroom or in the principal's office with the researcher and the teacher. The interviews lasted 3 weeks, and during the interviews, the researcher both recorded audios and took some notes. At the end of the interview, she confirmed the notes she took by comparing them together with the teachers. In open-ended questions, some probe questions were asked and explained in the instant. These probe questions were changed and restructured according to each interviewer. In this context, questions such as the following were included: What problems/What difficulties do you encounter? Why do you encounter them? What steps do you have difficulty in evaluating? What are the outcomes?

\section{Data Analysis}

The findings of the research were analyzed by means of descriptive method. An extensive and rich description constitutes the basis of qualitative analysis. A cross-sectional analysis was performed in the analysis process. While performing a descriptive analysis in case studies, different people are taken into consideration. Cross-sectional analysis is performed for the analysis of the data obtained as a result of the interviews with structured or open-ended questions. Thus, the answers received for each question are grouped and divided into themes (Patton, 2002). In the descriptive analysis, direct quotations are frequently given to reflect the views of the individuals interviewed or observed. The data are presented either by the themes revealed by the research questions or by the themes revealed by paying attention to the questions asked during the interview and the observation process (Yildirim and Simsek, 2011). Interpretation and reporting of the data were executed with natural generalizations following the description of the findings (Stake, 1995). Accordingly, the following activities were performed:

Creating a framework for descriptive analysis; The data collected in the research are in the form of audio recordings and notes of the researcher. Working on audio recordings is a difficult and hard process, so the researcher must transform the recordings into a form for an effective and systematic study (Jupp, 1996). Thus, the researcher transformed the interviews with the teachers to a new form in the computer environment and determined the themes be gathered under the data in accordance with the research questions. In this context, 7 themes were determined.

Processing the data according to the thematic framework: The data were organized according to themes and sub-themes were created and edited. Some data were excluded. The data organized at this stage were reviewed by two experts and they were asked to sort the data according to the conceptual framework.

Identification of the findings: In the research report, the data organized according to the themes and sub-themes were defined, and the opinions of the participants were frequently 
included with direct quotations. Codes were used to describe whose opinion was included. Each teacher was given a code number and the opinions of the teacher in question are indicated in parentheses "(T.1)".

Interpretation of the findings: The findings obtained in the discussion phase were explained and associated, and their cause-effect relation was formed and compared with other studies. According to the themes and sub-themes, the opinions of the teachers were interpreted and reported based on the research questions.

During the research, studies were conducted to increase the validity and reliability of the findings, because validity and reliability are necessary criteria to ensure or increase the credibility of research results. "Detailed reporting of the collected data and the explanation of the researcher regarding how he obtained the results are among the significant criteria of validity in qualitative research" (Yildirim \& Simsek, 2011). The studies conducted within this scope are as follows: First of all, it was attempted to explain in detail the research process and how the findings were obtained. Then, Miles and Huberman's (1994) validity and reliability criteria were taken into consideration. In this respect, the findings related to the program were defined to ensure internal validity. Then, whether these were consistent within themselves or not were tested by considering the opinions of different researchers. The results were further studied by two academicians and found to be realistic. Based on the findings of the research, the estimates and generalizations were found to be consistent with the data. The method, environment and processes of the research were defined in detail to ensure external validity. The sample group is sufficient to allow for generalization because all the teachers were accessed. The findings obtained from the research were comprehensive and associated with other studies. The results and discussions include the necessary explanations for further research.

For reliability, the consistency and confirmability proposed by Lincoln and Guba (1985) were taken into account for reliability (cited in Erlandson et al., 1993). In order to ensure consistency, the researcher asked the questions to each interviewer with the same approach and recorded them. These interviews were listened to by two other experts and they checked the coding of the data. They also expressed their views on the establishment of the relationship of the findings with the results, the explanations, and the discussions. In the second stage, the confirmability, the researcher gave the sub-themes with the themes he created and the interview inventory he received from the teachers to the two faculty members in the same faculty; and were asked to divide the opinions of the teachers into subthemes according to the themes. The opinions of the experts were consistent with the views of the researcher. In addition, when the experts compared the results obtained with the interview records, they stated that the data confirmed the results. The researcher kept the interview records and transcripts for use if necessary. For the reliability of the research, the reliability formula proposed by Miles and Huberman was used (1994). According to Reliability = Consensus / (Consensus + Disagreement), the reliability of the study was calculated as $90 \%$. According to Miles and Huberman, the reliability of the research should be over $70 \%$ (Miles and Huberman, 1994). In this context, the result of this calculation shows that the research is reliable. 


\section{Findings}

In the study, 18 teachers who educate children aged between 0-36 months were reached. The demographic characteristics of the teachers who participated in the research are as follows:

Table 1. Demographic Information of Teachers

\begin{tabular}{|c|c|c|c|c|c|c|c|c|c|c|c|c|}
\hline \multirow[b]{2}{*}{ Gender } & & \multicolumn{6}{|c|}{ Educational Background } & \multirow{2}{*}{\multicolumn{5}{|c|}{$\begin{array}{l}\text { Professional } \\
\text { experience (Year) }\end{array}$}} \\
\hline & & \multicolumn{2}{|c|}{$\begin{array}{l}\text { High } \\
\text { scho } \\
\text { ol }\end{array}$} & \multicolumn{2}{|l|}{$\begin{array}{l}\text { Associate } \\
\text { Degree }\end{array}$} & \multicolumn{2}{|l|}{$\begin{array}{l}\text { Undergrad } \\
\text { uate }\end{array}$} & & & & & \\
\hline $\begin{array}{l}\text { Fem } \\
\text { ale }\end{array}$ & $\begin{array}{l}\text { Ma } \\
\text { le }\end{array}$ & $\begin{array}{l}\text { High } \\
\text { Scho } \\
\text { ol }\end{array}$ & $\begin{array}{l}\text { Vocatio } \\
\text { nal } \\
\text { High } \\
\text { School }\end{array}$ & $\begin{array}{l}\text { Child } \\
\text { Develop } \\
\text { ment }\end{array}$ & $\begin{array}{l}\text { Oth } \\
\text { er }\end{array}$ & $\begin{array}{l}\text { Pre-school } \\
\text { teacher }\end{array}$ & $\begin{array}{l}\text { Child } \\
\text { Develop } \\
\text { ment }\end{array}$ & 1 & 2 & 3 & 4 & $\begin{array}{l}5 \\
\text { and } \\
\text { abo } \\
\text { ve }\end{array}$ \\
\hline 18 & - & & 4 & 8 & 6 & & & 1 & 3 & 7 & 5 & 2 \\
\hline
\end{tabular}

According to the table, all the teachers are female. When the educational levels of the teachers are examined, it is seen that there are 4 teachers who graduated from vocational high schools, 14 teachers with associate degrees, 8 teachers who graduated from the department of child development and 6 teachers who graduated from other departments. There are no teachers with undergraduate degrees. As for the professional experience, there are 2 teachers with 5 years of experience or above, 5 teachers with 4 years of experience, 7 teachers with 3 years of experience; 3 teachers with 2 years of experience and 1 teacher with 1 year of experience.

In the last five years, the information about the children and teachers in the Day Care Centres and Nurseries in Malatya is as follows:

Table 2. Number of Day Care Centres and Nurseries, and Teachers

\begin{tabular}{lllll}
\hline Year & $\begin{array}{l}\text { Day } \\
\text { Care Centre }\end{array}$ & $\begin{array}{l}\text { Day Care Centre } \\
\text { And Nursery }\end{array}$ & Number of children & Number of teachers \\
\hline $\mathbf{2 0 1 3}$ & 3 & 11 & 930 & 46 \\
$\mathbf{2 0 1 4}$ & 3 & 13 & 1080 & 54 \\
$\mathbf{2 0 1 5}$ & 3 & 10 & 955 & 47 \\
$\mathbf{2 0 1 6}$ & 4 & 7 & 775 & 38 \\
$\mathbf{2 0 1 7}$ & 4 & 7 & 972 & 48 \\
\hline
\end{tabular}

Source; Malatya Directorate of Social Services Archive, 2017

18 teachers, who educated infants and children aged o to 36 months old in all day-care centers, nurseries and day-care centers in the province, were accessed. The questions were prepared as open-ended questions and asked in an interview fashion. Following the openended questions, probe questions were asked, and they varied as per interviewer.

According to the data obtained, seven top themes - Development areas and indicators in the program, evaluations, issues that teachers pay attention to when planning activities, resources they use when planning activities and activities, types of activities designed by teachers, family participation, suggestions of teachers for the program - and the following relevant sub-themes appeared in the interviews: 
Table 3. Themes

\begin{tabular}{|c|c|}
\hline Theme & Sub-theme \\
\hline Developmental areas and & 1. Cognitive domain \\
\hline \multirow[t]{4}{*}{ indicators in the program } & 2. Psychomotor domain \\
\hline & 3. Language domain \\
\hline & 4. Self-care skills \\
\hline & 5. Social-emotional domain \\
\hline \multirow[t]{3}{*}{ Evaluations } & 1. Evaluation of the child \\
\hline & 2. Evaluation of activities \\
\hline & 3. Evaluation of the program \\
\hline \multirow[t]{2}{*}{$\begin{array}{l}\text { What teachers pay attention to } \\
\text { when planning activities }\end{array}$} & $\begin{array}{l}\text { 1. Age status of children/babies (monthly) and their developmental } \\
\text { level }\end{array}$ \\
\hline & $\begin{array}{l}\text { 2. Children's / babies' interests and whether they're willing to do } \\
\text { the activities }\end{array}$ \\
\hline \multirow{2}{*}{$\begin{array}{l}\text { The activities and the sources } \\
\text { used to plan the activities }\end{array}$} & 1. Ready plans purchased by the Institution \\
\hline & $\begin{array}{l}\text { 2. The Internet } \\
\text { 3. Former plans }\end{array}$ \\
\hline \multirow[t]{2}{*}{$\begin{array}{l}\text { The most designed activities by } \\
\text { teachers }\end{array}$} & $\begin{array}{l}\text { 1. Game activity } \\
\text { 2. Music activity }\end{array}$ \\
\hline & $\begin{aligned} \text { 3. Art activity } & \\
\bullet & \text { Cutting-Sticking } \\
& \bullet \text { Scissors activities } \\
& \bullet \text { Playdough }\end{aligned}$ \\
\hline \multirow[t]{2}{*}{ Family Participation } & 1. Values education \\
\hline & 2. Informing the parents \\
\hline \multirow{3}{*}{$\begin{array}{l}\text { Teachers' suggestions for the } \\
\text { program }\end{array}$} & 1. Evaluation of developmental indicators \\
\hline & 2. Preparation of plans \\
\hline & 3. Activity book \\
\hline
\end{tabular}

Objective 1. What are the views of the teachers in terms of the suitability of the development and its indicators in the program for the children? Findings for this question

The theme of developmental areas and indicators has six sub-themes: cognitive domain, psychomotor domain, language domain, social-emotional domain, and self-care skills. The teachers evaluated the development and indicators based on their ability to design activities that could provide them. Accordingly, the following opinions were stated: One of the teachers stated that the characteristics mentioned in the area of development were compatible with their children but that they had difficulty in realizing some of the indicators in the cognitive domain. $T_{2}$ also stated that the indicators were carried out by children over a long period of time and that they had difficulty in designing activities for indicators in the cognitive domain. Another teacher, $T 7$, said that she designed the art activities while realizing the indicators of the easiest motor development. T9 stated that she used storytelling activities in order to realize the indicators in language development, designed the activities for the indicators of self-care and motor development and had difficulty in designing activities in the cognitive domain.

T12 said "When teaching self-care skills, there must be an adult around, when eating, sleeping or using the restroom. We send evaluation letters to the families. However, even if the parents claim that their kids can take care of themselves in the restroom or eat by themselves, they still need someone or a teacher to help them. It is normally not included in the form. But we tolerate it anyway. We also have inclusive students, and we are having difficulties while giving 
developmental indicators. There are no indicators of development for them. The teacher has to deal with them one-to-one. We can't give them the normal developmental indicator when doing the native language activity." Here, she stated that teaching self-care skills in this age group were difficult because there were no developmental indicators for inclusive students.

A teacher T11 said that self-care skills and motor development did not fit with children in their group. For example, " she says they can button up on their own, but mine can't, or can't hold the scissors ". Here, she found the developmental indicators in the social-emotional domain to be compatible but did not find self-care skills compatible.

T13 pointed out the individual differences and said that some children did not comply with the developmental characteristics. She said that she usually had difficulty preparing activities for indicators in the psychomotor domain and did not know how to provide these indicators. T8 stated that developmental indicators of language and cognitive domain were above the mentioned age group (compared to the children in her group). She exemplified it with the fact that a 20-month-old baby knew his 5 organs, however, her children only knew about mouth, eyes, and nose.

When the teachers evaluated the areas of development, $T_{4}$ said that the characteristics of the developmental area given in the program did not fit for the age of 2 and stated that they had difficulty in planning the activities for this age group. T16 stated that the characteristics of the developmental area were more compatible with the age of 4. Another teacher, T14, expressed that the stated developmental characteristics were above the developmental characteristics demonstrated by children.

Objective 2. How do teachers evaluate? Findings for this question

This theme has 3 sub-themes: evaluation of the child, evaluation of the activities, self-evaluation of the educator. The answers of the teachers related to Objective 2 were concentrated on under the sub-theme of the evaluation of the program.

In the sub-theme of the evaluation of the activity, only one teacher made an evaluation and said; T16: "If I am unable to do the activities mentioned in the daily plan, I come back to them and do them in the following days".

In the sub-theme of the evaluation of the child, teachers used the development observation form to evaluate the children. Generally, at the end of the day, the families were informed about the activity performed in the classroom, and an evaluation was made. In addition, the teachers evaluated the child according to whether they performed the activity. For instance, T2 said: "I evaluate children according to the activities they do. I do not make monthly evaluations to evaluate children. I only give daily feedback to families. I do not have the evaluation form etc."

T5 said: "I make my evaluations daily as well as weekly and monthly. I do it at the end of the month. To check if I succeeded. Repeating is a part of my evaluation method. If he manages to do it when I tell him to repeat, I give him a pass. If he can't do it, I give it to him again. These are my evaluations for psychomotor domains. I do not use a different method for other areas. I check the overall progress in all the developmental areas and indicators in the program." and "I have difficulty in making an evaluation for the emotional domain." 
T11 said that she had difficulty while making an evaluation in the categories such as "partially can do" which requires a clear answer in the development observation form. She said that she made these evaluations according to her observations. She also stated that she noted her observations in a notebook and then shared the notes with the families; and that she used these notes for monthly evaluation.

No findings were obtained for the self-evaluation of the educator sub-theme.

\section{Objective 3. Teachers';}

a) What are the points they pay attention to when preparing the activities? Findings for this question

Teachers focused on two sub-themes; the developmental characteristics of children/babies, their levels and interest in the activity. According to the sub-theme of the developmental characteristics of children/babies, teachers generally took into account the developmental stage of the children. They emphasized children's developmental levels by selecting the activities they could do. Regarding the levels of the children, T2 stated that if the activity was not suitable for the child's level, she did some parts of the activity all by herself. Similarly, T4 said that some of her children were two years old and that she helped them use the scissors.

Another teacher, $T 7$, who had a younger age group, stated that children spent time with playdough as they usually slept. One teacher (T8) said that, in her group, there were babies with 16-17-19-20 months of age and that she checked whether these activities given to her were suitable for the babies and added: "I can't ask them to talk about colours, I only let them hold the rattle in their hands because they are so young. For example; in today's activity, there was a tower building game with music. The 20-month-old baby was able to perform this activity, but the 16-month-old baby failed to do so." Here, she highlights the fact that the activity changed according to the developmental characteristics of the babies. Similarly, T6 also said that it was also important for the activity to be in accordance with the monthly plan along with the developmental levels of the children.

T11 refers to both developmental characteristics and interests of children and says: "They must be such activities that the child should be able to understand and do them. They should understand it when I show them an animal figure. If they're complicated, they can't grasp them. It is important for me to have rich and comprehensible content. I want them to be able to colour it easily. The area for tearing and sticking activity should be wide and should allow them to accomplish the task, otherwise, if they fail, they get really sad. That's why I try to make them happy and be careful to choose the activities they can do."

According to the sub-theme of the children's interest in the activity, T1 takes into consideration whether the children are bored or not. She said that she continued with the activity if the child liked it, if the child did not like the activity, she changed it. T15 said: "Children should enjoy the activities. You should never bother them. This is important. It is important to make the activities more appealing to them." Another teacher, T3, said that she chose activities the children could do and have fun with. One of the teachers (T5) stated that she planned her activities in an open-minded manner and first weekly and then monthly and that she spread her activities over the days for that week. She said: "I give clear explanations to the kids, so the activity is always appealing for them!". 
b) What are the resources the teachers use when planning activities? Findings for this question

The sub-themes of this theme consist of the ready plans purchased by the institutions, the internet-based sites and the old activity files of the teachers. Institutions purchased monthly journals from the publishing houses and used the ready plans that came with the journals.

According to the sub-theme of the ready plans, T11 said: "Our plans come from the publishing houses. We use those plans. We do not prepare a plan. But sometimes, I do change the plans ". Teachers who used the ready plans purchased by the institution did not like these plans very much. For example; T3 said: "I'm using additional sources and sets we bought from publishing houses. I'm not happy with the sets. They are not suitable for the age groups." In addition, some teachers who used these journals did not even plan anything. They just studied the journal. T7: "The books came as a set. We do activities suitable for each age group." This shows that they did not plan anything for the day, instead, they only did what was provided in the purchased book.

According to the Internet sub-theme, T10, one of the teachers benefiting from the Internet, preferred the activities online insisting that they were up to date. Similarly, T16 said: "I usually do projects using the internet. If I find something that I believe the kids can do, I do it." Teachers said that it was easier to find activities on the internet and that there were so many varieties. Some teachers said they benefited from the Internet and publishers and the old books they used. Some of them only used the internet and others used only the plans they bought. For example, while T2 fully benefited from the Internet, T17 said: "I don't have sources, I investigate the sources the school gives us, or I look through the internet. Mostly, the sources from the internet".

In the sub-theme of the activity files of teachers, T14 said "I use both my files and the internet. I often use the files that I prepared when I was in high school."

The only teacher (T8) who stated that she had benefited from the program booklet prepared by the Ministry of National Education said the following: "In the book, each domain has a learning process such as the social-emotional domain, and the developmental characteristics of the children are stated. For instance, if it says in the booklet that a 16-month-old baby can do a certain activity, and if my baby is unable to perform it, I elaborate on it."

c) What are the most designed activities? Findings for this question

Teachers stated that they gave importance to muscle development, values education, and language development while designing activities and they planned their activities accordingly. Hence, the sub-themes of this theme are as follows: game, finger game, music, artwork and values education.

One of the teachers who designed art activities, T10, said "Usually, the muscular development is important, so I let them use the scissors one day, giving them the task of tearing and sticking another day or let them play with the dough the other day. Rolling the following day. It is important for me to develop small muscle development. T15 said "tearing and sticking is a waste of time, I make them squeeze the dough frequently for their muscles to develop" while T7 said: "So we give them the dough to improve their hands". 
T1, who said that the values were definitely included in the education, stated: "They grasp the art activities over time. What I care about is teaching values. Other activities already emerge as a routine in education. At the beginning of the year, we assessed the private publishing houses for this matter. And we use their books. Other things are the activities we already need to give them. But values education must be given no matter what".

The music activities teachers designed often involve singing and playing the finger game. T4 said: "I usually teach songs every day because the age group is really young. I give the songs in the form of finger games. I do not give so many art activities. I always give the songs in the morning and evening". T14, who designs game activities, stated that she liked game activities, finger games and music activities. T9 stated that the game is very important for 3-year-old children. T12 said: "Mother tongue activity is a must for children, and at 3 years of age, playing games is also important. We dramatize stories". T11 said: "Having conversations with the children is the activity I always go for. They really like the story, too"

\section{d) Findings of the question of the inclusion of family participation in teachers' activities}

In the family participation activities, the teachers used the parent information method. They informed the parents by sending home the activity performed during the day or a new activity, or when parents were dropping their children to school or picking them up from school.

T2 said: "I see the families every day. I do not engage in family participation". T3 said: "I already meet parents in person instead of family participation. I have meetings. We see each other while they pick up their children. They visit our classrooms, or I call them, and we talk when there is a problem. For example, they tell us that children don't eat, and we make them like eating. By playing and clapping".

T5, who planned family participation in her activities, stated: "Family participation is like asking whether they can send something to school or talk about a subject at home to ensure family participation. I also give weekly homework to allow them to do it together as a family. I have a monthly schedule. I tell them things like 'talk to your child today or cook pasta with your child at the weekend.' A copy of the plan is for me and the other copy is for the family. I talk to them on Monday to get feedback."

e) What are the suggestions of the teachers for the program? Findings for this question

The sub-themes of this theme consist of the evaluation of developmental areas and indicators and the preparation of the activities. For the first sub-theme, T4 said: "Developmental indicators are very few in guiding books; the evaluation of learnings is given in general. No direction is provided. The explanations regarding the evaluation of developmental indicators are brief and to the point. I wish they could be more explanatory".

T8, who wants these activities to be distributed to all the nurseries by the ministry of National Education, said: "National Education should also give plans to nurseries, and we must implement them. Private publishing houses should not give any plans. Specific plans should be prepared for all the teachers and that program must be formed by one body. It should be single and standard." 
Most of the teachers wanted more examples of activities. They especially wanted more game examples to be prepared and presented in different play styles. Some of them wanted diversity in art activities. T9 also criticized that the plans they used were for half a day and said that full-day plans should be prepared.

\section{Discussion, Conclusion, and Suggestions}

According to the findings obtained from the research, the following results have been obtained:

1. Teachers working in nurseries are generally high school graduates or have associate degrees. In order to be a teacher in the official schools of the Ministry of Education, it is required to graduate from the faculties of education in universities. In these faculties, besides the field knowledge, vocational knowledge and pedagogical formation courses are taught. However, these conditions are not required for teachers working in Nurseries and Day Care Centres under the Ministry of Family and Social Policies. As a matter of fact, none of the teachers participating in the study have bachelor's degrees and they do not have pedagogical content knowledge. According to this, teachers are inadequate and unequipped in terms of their field knowledge.

2. Teachers had difficulty designing activities to realize the indicators in the cognitive domain, self-care domain and psychomotor domain. They stated that they were looking for sample activities and that they could not prepare an activity in accordance with the indicators. Most of the teachers stated that the specified development indicators were not suitable for children, in other words, they were above the developmental levels of the children. Therefore, children in their own classes did not exhibit the aforementioned behaviours.

3. The result of the evaluation of the program showed that only one teacher made an evaluation in respect of multiple dimensions and evaluated the children according to both the activities at the end of the day and their developmental areas. However, one teacher had no knowledge of development checklists. Most teachers do not know how and how often an evaluation will be made. Teachers made the evaluation of the program based on the observation of the activities carried out in the daily educational flow. The evaluation of the child was performed using the monthly development checklist in general. The most difficult domain for teachers to evaluate is the evaluation of the emotional domain. In order to set an example for teachers who do not know how to make an evaluation in this domain, it may be suggested to develop scales to measure affective characteristics. Teachers never mentioned about the self-evaluation of the educators. In this context, it was found that teachers' knowledge about evaluation is insufficient and that they do not know how often and how they should make an evaluation.

Assessment and evaluation are among the mainstays of the training program (Demirel, 2011). Assessment is the observation of any entity, event or situation and is defined as the expression of the observation with numbers or other symbols (Turgut, 1988). Evaluation is a decision-making process that results in determining whether the assessment result (asset, event or situation) meets a certain condition (Ozcelik, 2013). Evaluation and Assessment have many important requirements such as measuring the extent to which the objectives determined by teaching were achieved, determining whether teaching methods and materials are appropriate for the purposes of teaching, recognition and placement of students and 
determining learning deficiencies and difficulties (Karaca, 2008). The aim of the evaluation in early childhood education is to learn about children, to consider their individual needs, to choose appropriate materials, to determine the structure of the activities and the way of performing them.

In the early childhood education program, evaluations are performed in a multifaceted manner. As a matter of fact, evaluations in the educational program for infants and children aged 0 to 36 months old were taken into consideration in three dimensions: evaluation of the baby/child, evaluation of the program and self-evaluation of the educator (Milli Egitim Bakanligi, 2013). Considering the rapid development in early childhood and the environmental factors affecting this process, the assessments and evaluations should be carried out in a planned and professional manner, not randomly, in the early childhood period. When this is missing, a successful educational program cannot be achieved. In this regard, one can provide educators with methods to measure the developmental status of children and methods to evaluate the outcome.

\section{When teachers are planning activities;}

a) Attention is paid to whether the activities are in accordance with the levels of development of the children in terms of their age group, that is, months, and they should not be bored with the activity but have fun while doing the activities.

b) While planning the activities, the teachers continuously benefited from available sources, and therefore, did not use their original creativity. The most frequently consulted sources were the internet-based sites and the ready plans and activities of the publishers that the institutions worked with. In another similar study, prospective pre-school teachers stated that there was no need to prepare a plan since there were ready plans on the internet (Ramazan and Yilmaz, 2017). The characteristics that a teacher who gives early childhood education should possess are creativity and productivity and being able to plan teaching activities (Daglioglu, 2010). Moreover, there are those who think that these activity plans do not comply with the levels of development of the children in the classroom.

The teachers did not plan the daily educational flow while they made their educational plans, and some even heard the existence of a plan such as the daily educational flow for the first time.

c) When planning the activities, teachers did not give any place to science and mathematics activities. They mostly planned activities that would support musical activeness and motor development of children, such as games and finger games. In this respect, it was concluded that the support given to children's creativity was insufficient as other types of activities were not involved (science, mathematics, art). In addition, children were not supported in all the areas of development. In this context, the developmental feature of the program was not abided by. In early childhood educational programs, activities such as music, Turkish language, mathematics, science, play, drama, art, reading, and writing activities are planned. Besides, the teacher may also implement the original activities he/she deems necessary (Milli Egitim Bakanligi, 2013). According to the research conducted, drama, science, music, Turkish language activities, children's language development, mathematical ability, auditory reasoning, musical hearing skills, social-emotional development and creativity support facilitated social learnings and supported their developments whereas they also increased 
their creative thinking and problem-solving skills (Can Yasar and Aral, 2011, Canakay and Bilen, 2006, Duran \& Unal, 2016).

There are deficiencies in the theoretical knowledge of teachers. For example, one of the principles of development is from general to specific (Bayhan and Artan, 2009). For example, first, the big muscles develop, then the small muscles develop. Educational conditions should also be designed in accordance with the child's level of development. However, one of the teachers (T11) said that she planned the activities supporting the development of small muscles first, then she planned the activities supporting the development of bigger muscles. This situation is contrary to the course of development of children and causes them to face a challenging learning process. In addition, it is contrary to the goals of a successful education and nursery program (Sonmez, 2011) because one of the characteristics of the nursery program is its developmental aspect (Milli Egitim Bakanligi, 2013).

d) Teachers substantially limited family participation activities. They used only the information method from family participation activities. Family participation is the ability of parents, other members of the family, or those who take care of the children to have a good interaction with the educator, in other words, including them in the educational environment so that they can contribute to maximizing children's learning by making use of their abilities to strengthen the communication between the mother, father and child at home and to be a part of the education (Young, 1996; Priscilla, 1998; Epstein, 2002; George, 2003; Morrison, 2003; Tezel Sahin and Unver, 2005). As family participation activities in early childhood education, the following things can be performed: family educational activities, parent-group meetings, phone calls, parent corner, educational boards, newsletters, wish boxes, brochures, home visits, development reports, portfolios, video recordings, participation in classroom educational activities, news board, photos and writing messages (Tizard, 1993; Hunter, 2001; Leask, 2001; Eliason and Jenkins, 2003; Tezel Sahin and Ozyurek, 2010; Temel, Aksoy \& Kurtulmus, 2010). The research showed that parents' participation in education contributed positively to the development of children; it helped increasing the success at school, making it easier to adapt to the school, and also showed that parents were involved in the children's education in the later stages (Henderson and Berla, 1994; Celenk, 2003; Gumuseli, 2004). Family participation will increase the self-esteem of the children and help them to have more comfortable relationships with their teachers and parents, and it will also allow the other children in the family to benefit from this experience. Family participation also leads to an increase in parents' ability to become better parents and it also allows them to be more comfortable in their relationships. Considering all these, family participation is one of the indispensable elements of early childhood education. Parents should be a part of the education so that the education given in educational institutions is carried on. Therefore, the managers and educators in the educational institution should be attentive and sensitive in this regard. A family support training guide has also been prepared within the integration of the educational program for infants and children aged o to 36 months old and the pre-school educational program for infants and children aged o to 36 months old to improve family participation and communication. Family participation activities need to be diversified without being limited to a single dimension because education is a dynamic process. In this respect, it was determined that the teachers who participated in this study did not use their family participation activities sufficiently and they reported only the activities performed to the families. 
e) Teachers wanted to increase the number of sample activities. They said they had never heard of the educational program for infants and children aged o to 36 months old prepared by the Ministry of National Education and wanted the books to be handed to them. In addition, they asked the educators of the universities to give them seminars about the changes made.

\section{Suggestions}

The following suggestions may be proposed according to the results of the research;

a) Suggestions for researchers

1. To assess the development of the children in this age group, scales, the validity and reliability of which have been checked, can be developed.

2. New research can be conducted according to age groups.

\section{b) Suggestions for teachers}

Teachers working in these institutions should follow the current changes with their private initiatives and improve themselves on this issue. They should take initiatives to encourage the managers of the institutions to invite experts and organize seminars for necessary matters. Or they can get information about the developmental processes of children from the educators of pre-school teaching departments in the education faculties of the universities in the provinces they live in, and they can get information about the developmental processes of children by making appointments from the department of child development of health colleges, and they can ask to participate in classes.

\section{c) Suggestions for educational programmers}

1. Necessary institutions and universities should routinely provide in-service training to teachers working in day care centers and nurseries and keep them informed about changing programs and news as the majority of the teachers working in nurseries and day care centers are high school graduates or teachers graduated from associate degree programs. The majority of these programs are the programs other than pre-school or child development. In this context, teachers should be subjected to both pedagogical and programmatic training about the area. In addition, the managers of these institutions should make attempts to provide the necessary training for their educators.

2. Teachers working in these institutions can be trained on how to evaluate children/babies.

3. For infants and children with 0-36 months of age, books with a larger pool of activities (science, mathematics, art, Turkish language, game, drama, etc.) can be prepared and published by experts to introduce to the teachers that the educational program for infants and children aged o to 36 months old is separate from the pre-school educational program.

4. In the evaluation dimension, training explaining how to handle the stage of self-evaluation and requiring the use of the educational environment, methods-techniques and communication skills should be given to educators. 


\section{References}

Bayhan, S. P. \& Artan, I. (2009). Cocuk gelisimi ve egitimi. Istanbul: Morpa yayincilik

Canakay, U. E., \& Bilen, S. (2006). Okul oncesi muzik egitiminde orff ogretisinin muziksel beceriler uzerindeki etkileri; the effect of the orff schulwerk in preschool musictraining on musical skills. EJER (Eurasian Journal of Educational Research), 22, p. 48-60.

Celenk, S. (2003). Okul basarisinin on kosulu: okul aile dayanismasi”. Ilkogretim-Online. 2(2), 28-34. Erisim adresi:http://www.ilkogretim-online.org.tr

Creswell, J. W. (2007). Qualitative inquiry \& research design. Choosing among five approaches.(Second ed.) Thousand Oask, London, Sage Publications, Inc

Daglioglu, E., H. (2010). Erken cocukluk donemi ögretmeninin ozellikleri. I. H. Diken (Ed.) Erken cocukluk egitimi icinde (s.482-518), Ankara: Pegem akademi.

Demirel, O. (2011). Ogretim ilke ve yontemleri ogretme sanati. (17. baski). Ankara: Pegem akademi.

Derman, T. M. \& Basal, A. H. (2010). Cumhuriyetin ilanindan gunumuze Turkiye'de okul oncesi egitim ve ilkögretimde niceliksel ve niteliksel gelismeler. Uluslararası Sosyal Arastırmalar Dergisi, 3(11), 560-569.

Duran, M. \& Unal, M. (2016). The impacts of the tests on the scientific process skills of the preschool children. US-China Education Review A, 6 (7), 403-411.

Eliason, C. \& Jenkins, L. (2003). A practical guide to early childhood curriculum. Upper Saddle River, N.J.: Merrill Prentice Hall.

Epstein, J. L. (2002). School, family and community partnership: caring fort he children we share. California: Corvwin Pres.

Erlandson, D. A., Harris, E. L., Skipper, B. L. \& Allen, S. T. (1993). Doing naturalistic inquiry: A guide to methods. Beverly Hills, CA: Sage.

Gelisli, Y., Yazici, E. (2012). Turkiye'de uygulanan okul oncesi egitim programlarinin tarihsel surec icerisinde degerlendirilmesi. Gazi Universitesi Endustriyel Sanatlar Egitim Fakultesi Dergisi. (29), 85-93

George, S. M. (2003). Fundamentals of early childhood education. Upper Saddle River, New Jersey.

Gumuseli, A., I. (2004). The effect of family participation and support on student achievement. Private Schools Association Bulletin (2) 6, p.14-17.

Henderson, A. T. \& Berla, N. (1994). A new generation of evidence: the family is critical to student achievement. National Committee for Citizens in Education. Printed in U.S.A.

Hunter, C. (2001). Sunniva's extra pocket a parents reflections. Experiencing reggio emilia, implications for pre-school provisition. L. Abbot And C. Nutbrown (ED.), Open University Pres, Buckingham, Philadelphia, USA.

Jupp, V. (1996). "Documents and Critical Research", R. Sapsford \& V. Jupp (Ed.), Data Collection and Analysis. London: Sage.

Karaca, E. (2008). Olcme ve degerlendirmede temel kavramlar. Serkan Erkan \& Mufit Gomleksiz (Ed.) Egitimde olcme ve degerlendirme icinde (s.2-37). Ankara: Nobel yayinevi.

Kleyn, K. \& Shaughnessy, M. F. (2012). Handbook of early childhood education. Hauppauge, N.Y.: Nova Science Publishers, Inc.

Leask, J. (2001). Experiencing reggio emilia, implications for pre-school provisition. Lesley Abbot and Cathy Nutbrown (ED.), "sam's invisible extra gear a parents view, Open University Pres, Buckingham, Philadelphia, USA.

Merriam, S. B. (2009). Qualitative research: a guide to design and implementation. (3. Ed.), Jossey-Bass. 
Miles, M. B \& Huberman, M. (1994). Qualitative data analysis: An expanded sourcebook (2. Ed.). Tousand Oask, CA: Sage.

Milli Egitim Bakanligi. (2013). Okul Oncesi Egitim Programı (36-72 aylık cocuklar icin). Ankara.

Morpa Yayinlari (2010). 36-72 Aylık Cocuklar Icin Okul Oncesi Egitim Programı Ve Okul Oncesi Egitim Kurumları Yonetmeligi. Istanbul.

Morrison, G, S. (2003). Fundamentals of early childhood education. Upper Saddle River, New Jersey, Columbus, Ohio.

Ozcelik, D. A. (2013). Okullarda olcme ve degerlendirme ogretmen el kitabi. (2. Ed.), Ankara: Pegem publication.

Patton, M. Q. (2002). Qualitative evaluation and research methods (3. Ed.). Thousand Oaks, California, US: Sage Publications, Inc.

Priscilla, M. D. (1998). Family involvement in early childhood programs: how to choose the right program for your child. National institute on early childhood development and education of the office of educational research and improvement, U.S.

Ramazan, O., Yilmaz, E. (2017). Okul oncesi ogretmen adaylarinin okul deneyimi ve ogretmenlik uygulamalarina yonelik goruslerinin incelenmesi. Abant Izzet Baysal Universitesi Egitim Fakultesi Dergisi, 17(1), 332-349.

Sonmez, V. (2011). Ogretim ilke ve yontemleri. (6. baski) Ankara: Ani yayinlari.

Stake, R. (1995). The arts of case study research. Thousand oask, CA: Sage Publications, Inc.

Talim Terbiye Kurulu Baskanlıgı. (1981). 10. Milli Egitim Surası, 23-26 Haziran 1981 http://ttkb.meb.gov.tr/meb iys dosyalar/2017 09/29165120 10 sura.pdf

Tebligler Dergisi, Milli Egitim Bakanligi. (1989). Okul Oncesi Egitim Programi. 2293(52), p.557577 http://tebligler.meb.gov.tr/index.php/tuem-sayilar/finish/53-1989/677-2293-agustos1989

Tebligler Dergisi, Milli Egitim Bakanligi. (1994). Okul Oncesi Egitim Programi 2415(57), p.709 http://tebligler.meb.gov.tr/index.php/tuem-sayilar/finish/58-1994/468-2415-eyluel-1994

Tebligler Dergisi, Milli Egitim Bakanligi. (2006). Okul Oncesi Egitim Programi. 2588(69), p.1045 http://tebligler.meb.gov.tr/index.php/tuem-sayilar/finish/70-2006/210-2588-eyluel-2006

Tebligler Dergisi, Milli Egitim Bakanligi. (2013). Okul Oncesi Egitim Programi. 2673(76), p.1895 http://tebligler.meb.gov.tr/index.php/tuem-sayilar/finish/80-2013/1193-2673-ekim-2013

Temel, F. Z., Aksoy, B. A. \& Kurtulmus, Z. (2010). Erken coculuk egitiminde aile katilimi calısmalari. Z. Fulya Temel (Ed.), Aile egitimi ve erken cocukluk egitiminde aile katilimi calismalari icinde (s.327-361). Ankara: Ani yayincilik.

Tezel, S. F. \& Ozyurek, A. (2010). Anne baba egitimi ve okul oncesinde aile katilimi. Istanbul: Morpa yayincilik.

Tezel-Şahin, F. \& Unver, N. (2005). Okul oncesi egitim programlarina aile katilimi. Kastamonu Egitim Dergisi, 13(1). 23-30.

Tizard, M. B. (1993). Involving parent in nursery and infant schools: a source book for teacher, USA: The Hihg Scop Pres.

Turgut, M. F. (1988). Egitimde olcme ve degerlendirme metotlari. 6. baski. Ankara: Saydam

Turkiye Cumhuriyeti Resmi Gazete. (1953). Gebe ve emzikli kadinlarin calistirilma sartlariyla emzirme odalari ve kresler hakkinda nizamname. 8517/ 25.09.1953 https://www.resmigazete.gov.tr/arsiv/8517.pdf

Turkiye Cumhuriyeti Resmi Gazete. (1966). Saglik ve Sosyal Yardim Bakanlıgı'na bagli kres ve

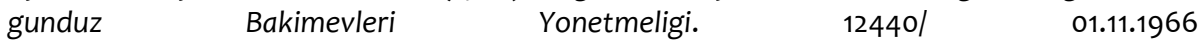
https://www.resmigazete.gov.tr/arsiv/12440.pdf

Turkiye Cumhuriyeti Resmi Gazete. (2016). Ozel kres ve gunduz bakimevleri ile ozel cocuk kuluplerinin kurulus ve isleyis esaslari hakkinda yonetmelikte degisiklik yapilmasina dair 
yonetmelik. $29935 / 2016$ https://www.resmigazete.gov.tr/eskiler/2016/09/20160908.pdf

Yasar, C. M. \& Aral, N. (2011). Turkiye'de okul oncesinde drama alaninda yapilan lisansustu tezlerin incelenmesi. Mehmet Akif Ersoy Universitesi Egitim Fakultesi Dergisi. 11(22), p.70 -90 .

Yildirim, A. \& Simsek, H. (2011). Sosyal Bilimlerde Nitel Arastırma Yontemleri.. Ankara: Seckin yayincilik.

Yilmaz, N. (2003). “Turkiye'de okul oncesi egitim”. M. Sevinc (Ed.), Erken cocukuk gelisimi ve egitimde yeni yaklasimlar icinde. S.12-17. Istanbul: Morpa yayinlari.

Young, A. (1996). Parental involvement in early childhood education, child policy relief, Georgia University, School Of Policy Studies.

\section{Biographical notes:}

Munise DURAN completed her PhD degree on child development and education at the Selcuk University in 2013. She is an Assistant Professor in the Department of Basic Educational of Preschool Teacher Programme at Malatya Inonu University, Turkey. Her current research interests are curriculum studies, teacher education, language education, social skills and values education in early childhood. 